\title{
Blocking premature reverse transcription fails to rescue the HIV-1 nucleocapsid-mutant replication defect
}

\author{
James A Thomas, Teresa L Shatzer and Robert J Gorelick
}

\begin{abstract}
Background: The nucleocapsid (NC) protein of HIV-1 is critical for viral replication. Mutational analyses have demonstrated its involvement in viral assembly, genome packaging, budding, maturation, reverse transcription, and integration. We previously reported that two conservative NC mutations, His23Cys and His44Cys, cause premature reverse transcription such that mutant virions contain approximately 1,000-fold more DNA than wild-type virus, and are replication defective. In addition, both mutants show a specific defect in integration after infection.

Results: In the present study we investigated whether blocking premature reverse transcription would relieve the infectivity defects, which we successfully performed by transfecting proviral plasmids into cells cultured in the presence of high levels of reverse transcriptase inhibitors. After subsequent removal of the inhibitors, the resulting viruses showed no significant difference in single-round infective titer compared to viruses where premature reverse transcription did occur; there was no rescue of the infectivity defects in the NC mutants upon reverse transcriptase inhibitor treatment. Surprisingly, time-course endogenous reverse transcription assays demonstrated that the kinetics for both the NC mutants were essentially identical to wild-type when premature reverse transcription was blocked. In contrast, after infection of CD4+ HeLa cells, it was observed that while the prevention of premature reverse transcription in the NC mutants resulted in lower quantities of initial reverse transcripts, the kinetics of reverse transcription were not restored to that of untreated wild-type HIV-1.
\end{abstract}

Conclusions: Premature reverse transcription is not the cause of the replication defect but is an independent side-effect of the NC mutations.

\section{Background}

The nucleocapsid (NC) protein of HIV-1 functions throughout the viral replication cycle, from involvement in assembly and genomic RNA (gRNA) packaging as part of the Gag protein (Pr55), to facilitating reverse transcription as a mature protein (p7). The mechanisms behind NC's ability to perform these roles have been extensively investigated both in vitro and in cell culture as detailed in the following reviews [1-8].

The role of $\mathrm{NC}$ in reverse transcription has been investigated in considerable detail using a number of excellent in vitro systems. Because of these thorough studies, we know that $\mathrm{NC}$ can facilitate the tRNA ${ }^{\text {lys3 }}$ annealing to the primer binding site [9-11], dramatically

\footnotetext{
* Correspondence: gorelicr@mail.nih.gov

AIDS and Cancer Virus Program, SAIC-Frederick, Inc., NCl at Frederick, Frederick, MD 21702, USA
}

enhance the efficiency of minus-strand and plus-strand transfer events [12-19], prevent self-priming (a suicidal reaction) $[13,15,18,20,21]$, and enhance the processivity of reverse transcription [22-25]. In addition to reverse transcription, $\mathrm{NC}$ has also been demonstrated to enhance coupled integration events in vitro [26]. The fact that NC can assist in all of these processes directly proceeds from its properties as a nucleic acid chaperone, which means that $\mathrm{NC}$ assists nucleic acids to find the most thermodynamically stable arrangement resulting in maximum base pairing [1,2]. Although the general properties of $\mathrm{NC}$ as a nucleic acid chaperone were observed many years ago in vitro [17,27], the mechanics of how these properties govern NC's actions during reverse transcription is still being elucidated.

We have been interested in examining how NC mutations affect reverse transcription in virions and infected

\section{Biomed Central}


cells. Two particular mutants of $\mathrm{HIV}-1, \mathrm{NC}_{\mathrm{H} 23 \mathrm{C}}$ and $\mathrm{NC}_{\mathrm{H} 44 \mathrm{C}}$, have proven to be of great interest in that although the amino acid alterations are functionally conservative with respect to zinc binding, genome packaging, and virion assembly, the resulting viruses are replication defective [28-30]. Our initial studies revealed an apparent defect in viral DNA (vDNA) stability and integration after infection [31]. After a more detailed kinetic analysis, we were able to directly demonstrate that integration efficiency was severely impaired for both of these mutants [32]. Intriguingly, these data also suggested that these NC mutations appear to cause reverse transcription to initiate much earlier than in wild-type infections. When we examined the nucleic acids present in NC-mutant virions prior to infection, we found that they actually contained a significant amount of vDNA $(\sim 1,000$-fold more than WT [33]); virtually every particle had initiated reverse transcription, and so this process is apparently occurring prematurely in the viral replication cycle. Similar results have also been reported by another group with these and other HIV-1 NC-mutant viruses [34,35]. The exact cause and the significance of this premature reverse transcription are unknown $[33,36]$.

We hypothesized that premature reverse transcription alone may have been sufficient to block replication of these viruses. Therefore, we attempted to block premature reverse transcription in the NC mutants using reverse transcriptase inhibitors (RTIs) rather than reverse transcriptase (RT) active site mutations. This choice was made because arresting reverse transcription with inhibitors is potentially reversible, which would enable us to assess how well blocking premature reverse transcription affects viral replication. Additionally, we have observed that active site point mutations in RT can cause unwanted alterations in Gag processing (data not shown). A previous study demonstrated the feasibility of reducing intravirion DNA by greater than $97 \%$ by the addition of $50 \mu \mathrm{M}$ Nevirapine (NVP); treatment with $50 \mu \mathrm{M}$ azidothymadine was only able to reduce intravirion DNA by $75 \%$ [35].

\section{Results}

Reverse transcriptase inhibitors prevent infection and can be effectively removed from virus preparations

Initial experiments were performed to determine the necessary concentrations of RTIs to use and we found that a single inhibitor was insufficient to block the levels of premature reverse transcription that the NC mutations were causing (data not shown). Virtually every NCmutant virus particle contains minus-strand strong-stop DNA [33], which is extremely difficult to prevent because it is much more difficult to inhibit the synthesis of short reverse transcripts (i.e., minus-strand strong-stop DNA) [37] required for these studies. In contrast, viral replication can be blocked if the synthesis of the full-length reverse transcript is stopped at almost any point. We ultimately found that in order to effectively stop premature reverse transcription, we needed to add very high concentrations of two different RTIs to cells, immediately before transfection of proviral plasmids: $1.0 \mathrm{mM}$ Tenofovir (PMPA) and $50 \mu \mathrm{M}$ NVP. These two drugs target RT differently; PMPA is a nucleotide reverse transcriptase inhibitor (NRTi) that must be incorporated into the nascent DNA while NVP is a non-nucleoside reverse transcriptase inhibitor (NNRTi). The concentrations of each inhibitor required to completely prevent intravirion DNA synthesis were more than 1,000-fold higher than their $\mathrm{IC}_{50}$ levels in cell culture (PMPA: $\mathrm{IC}_{50}=0.1-0.6 \mu \mathrm{M}$ [38], NVP: $\mathrm{IC}_{50}=40 \mathrm{nM}$ [39]).

However, our investigations required determining the properties of virions after premature reverse transcription had been blocked, so we developed two different methods (Figure 1) to remove excess RTIs from virus preparations once particles were released from the

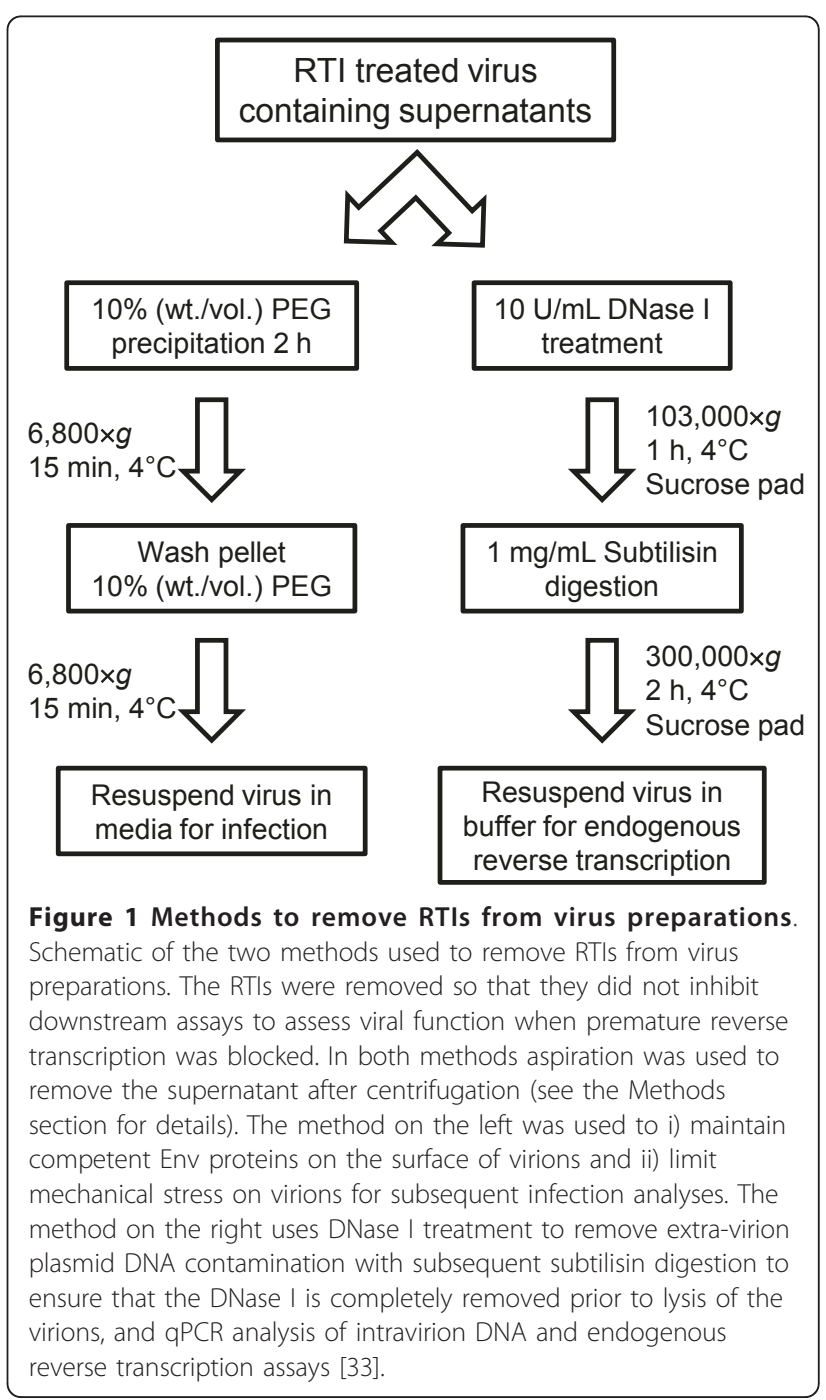


producer cells and premature reverse transcription could no longer occur. Key to both of these methods is the collection of the virus particles for complete media replacement, which reduces the concentration of RTIs to levels far below what would interfere with reverse transcription. For subsequent infectivity experiments, we precipitated virus from culture supernatants with polyethylene glycol (PEG 8000) at $4^{\circ} \mathrm{C}$ (Figure 1, left). In contrast, for subsequent assessment of intravirion DNA levels and endogenous reverse transcription assays, we used our previously reported protocol for preparing virions (Figure 1, right; [33]); this rigorous protocol was found to be essential for removal of extra-virion contaminating plasmid DNA to enable accurate determinations of intravirion DNA levels [33]. However, virus treated by the latter method, which entails subtilisin digestion to inactivate the DNase I prior to lysing the virions cannot be used for infectivity assays as all membrane surface proteins, including Env, are digested [40].

Identifying effective methods for removal of RTIs was initially performed using the VSV-G pseudotyped HIV-1 system that we previously employed [33]. Figure 2 compares single-round TZM-bl infectivity over a serial dilution series [41] of untreated or RTI-treated VSV-G

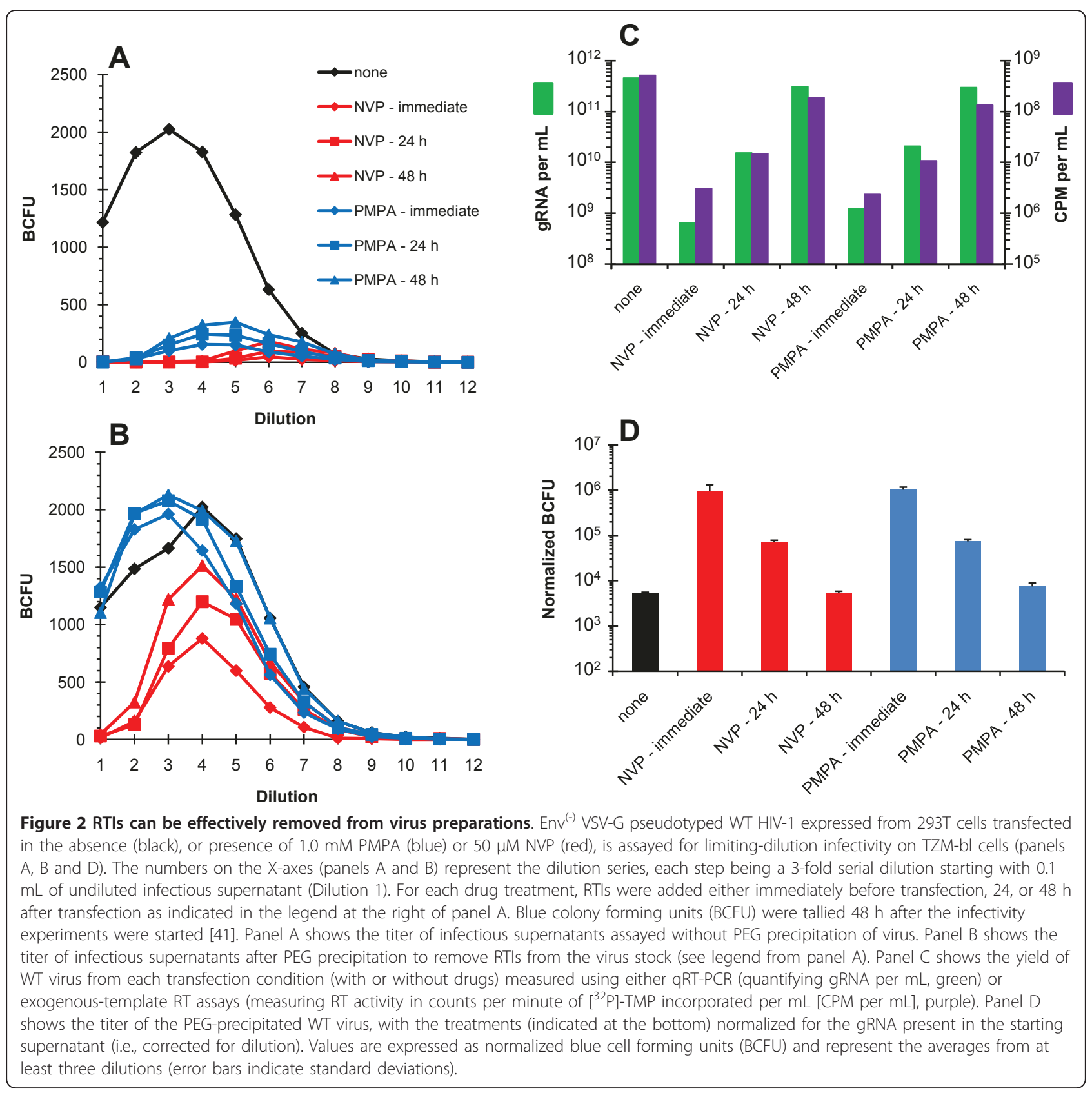


pseudotyped $\mathrm{NC}_{\mathrm{WT}}$ virus preparations without (panel $\mathrm{A}$ ) or with (panel B) PEG precipitation. It is important to note that the titer of untreated virus (black line) is the same, whether the virus was PEG precipitated or not. However, the titers of viruses treated with either NVP (red lines) or PMPA (blue lines) are much lower if the RTIs are not removed (compare panels A and B, red and blue lines). NVP appears to be more difficult to remove than PMPA as the peak in PMPA-treated viruses occurs at a lower dilution than the peak in NVP-treated virus. This may be due in part to their different modes of action (NRTi vs NNRTi) so that the dATP present in the infected cells competes with any remaining unincorporated PMPA in the preparations. This difference also correlates with the relative effective concentrations of the two drugs (PMPA is effective in the $\mu \mathrm{M}$ range while NVP is effective in the $\mathrm{nM}$ range). Interestingly, because PMPA is a chain terminator, it functions by being incorporated into the nascent vDNA and thus would not be affected by reducing its concentration in the media. However, it has been shown that WT RT has the ability to excise nucleosides, including PMPA in vitro $[42,43]$ and NC can facilitate excision processes, possibly by stabilizing RT on the nucleic acid template $[42,44]$. As will be shown in our assays below, removal of RTIs is essentially complete.

The fact that the wild-type virus used for the experiments in Figure 2 was VSV-G pseudotyped demonstrates another effect of the RTI treatment. Pseudotyping HIV-1 boosts the infectious titer of the virus produced in part by increasing the total number of virus particles (Figure $2 \mathrm{C}$ ). These additional particles are the product of VSV-G pseudotyped virus infecting the transfected cells, which we showed previously could be inhibited by PMPA treatment of the transfected cell culture [33]. If one compares the yield of virus as a function of the treatment, one sees that the amount of virus produced decreases the earlier RTIs are added during the transfection (Figure 2C). In this chart, virus yields are determined using either quantitation of genomes by qRT-PCR or exogenous-template RT activity. Importantly, these two assays are in excellent agreement, which shows that the RTIs have been effectively removed and do not significantly affect the exogenoustemplate RT activity. For the majority of subsequent experiments, gRNA quantitation is used, because it is the most relevant for determining the efficiency of reverse transcription; vDNA results are normalized on a per genome basis throughout. The later RTIs are added during the transfection, the closer the virus yield approaches that of the untreated virus so that if RTIs are added $48 \mathrm{~h}$ after the DNA-precipitate is applied to the $293 \mathrm{~T}$ cells, there is essentially no effect on virus yield. We conclude that immediate addition of RTIs to the transfected cells inhibits VSV-G mediated reinfection completely because virus yield is no different from that obtained from transfections without VSV-G (see below).

While addition of RTIs to transfected cells at earlier times decreases virus yields, we observed a corresponding increase in the infectivity per virion (Figure 2D). When RTIs are present from the immediate onset of the transfection, the infectivity per particle is approximately 180 -fold higher than virus produced without RTIs (compare black bar with red and blue "immediate" bars). If RTIs are added $24 \mathrm{~h}$ after the transfection, the infectivity per particle is only 13 -fold higher. Finally if RTIs are added $48 \mathrm{~h}$ post transfection, the infectivity per particle is nearly the same as virus produced without RTI exposure (Figure 2D). The decrease in relative infectivity is likely due to an accumulation of defective genomes (from the VSV-G pseudotyped wild-type virus reinfection of the transfected cells mentioned above) producing non-infectious particles because the reverse transcription process is inherently error-prone [45]. We know from previous studies that in this system a replication cycle occurs every $24 \mathrm{~h}$ [46], thus virions have undergone 2 rounds of replication while being generated, and genomes are no longer transcribed solely from transfected plasmids.

\section{RT inhibitors can block premature reverse transcription}

For the remainder of this study we chose to use nonpseudotyped, Env ${ }^{(+)} \mathrm{HIV}-1$ for several reasons: i) so we do not need to be concerned with reinfection of transfected cells with the wild-type virus (without RTI treatment) and ii) it was noted previously that VSV-G pseudotyped NC-mutant HIV-1 did not undergo this amplification since the $\mathrm{NC}$ mutants are replication defective, thus there will not be the tremendous difference in the numbers of particles produced between VSV-G pseudotyped NC-mutant and wild-type HIV-1 that was reported previously [33]. This makes comparisons of results between untreated and RTI-treated samples more straightforward.

We transfected 293T cells cultured in the presence of both PMPA and NVP with NC-mutant and wild-type proviral plasmids and changed the media after $24 \mathrm{~h}$, adding fresh RTIs to maintain concentrations as high as possible. We harvested virus $24 \mathrm{~h}$ later, treated with DNase I and subtilisin to remove extra-virion contaminating plasmid DNA (Figure 1, right), and measured intravirion DNA by quantitative PCR (qPCR) to assess the levels of minus-strand strong-stop (R-U5), minusstrand transfer (U3-U5), late minus-strand synthesis (Gag) and plus-strand transfer (R-5'UTR) targets, and also gRNA as previously described [33]. Figure 3 shows that using this method we could quite significantly 


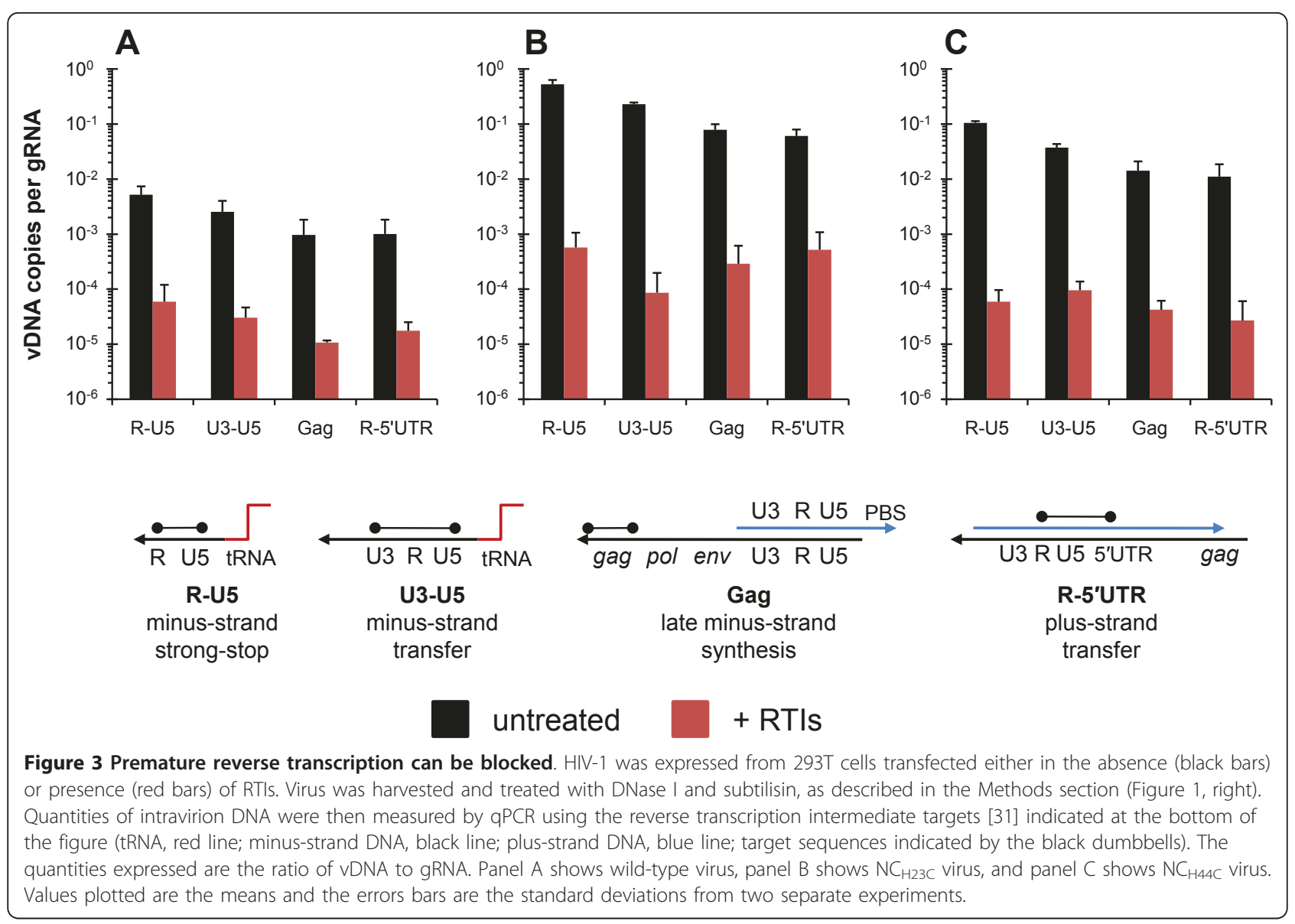

(>99.9\%) reduce intravirion $\mathrm{R}-\mathrm{U} 5$ DNA in the $\mathrm{NC}$ mutants to levels below those observed for untreated wild-type virus (compare red bars in panels $B$ and $C$, with black bars in panel A). When one compares the quantities of intravirion DNA per gRNA, between untreated and RTI treated samples, there is a 60- to 90fold reduction of intravirion DNA in WT virions (panel A), a 120 - to 2,600-fold reduction in $\mathrm{NC}_{\mathrm{H} 23 \mathrm{C}}$ virions (panel B), and a 340- to 1,800-fold reduction in $\mathrm{NC}_{\mathrm{H} 44 \mathrm{C}}$ virions (panel $\mathrm{C}$ ), depending on the vDNA target.

After blocking premature reverse transcription, levels of intravirion DNA per gRNA are very similar between wild-type and the $\mathrm{NC}$ mutant virions (compare red bars between panels $\mathrm{A}$ with $\mathrm{B}$ or $\mathrm{C}$ [i.e., $\mathrm{NC}_{\mathrm{H} 23 \mathrm{C}}: \mathrm{NC}_{\mathrm{WT}}=3$ to 30 -fold difference or $\mathrm{NC}_{\mathrm{H} 44 \mathrm{C}}: \mathrm{NC}_{\mathrm{WT}}=1$ - to 4 -fold difference, respectively, depending on the vDNA species]).

\section{Blocking premature reverse transcription has no effect on infectious titer of viruses}

Figure 4 displays the efficacy of PEG precipitation on removing $\mathrm{RTIs}$ from $\mathrm{NC}_{\text {mutant }}$ and $\mathrm{NC}_{\mathrm{WT}}$ virus preparations. Figure 4A shows the yield of viruses produced in the absence or presence of RTIs, expressed as exogenous-template RT activity (in CPM per $\mathrm{ml}$ ). One can see that the RT activities are slightly lower in preparations of viruses generated in the presence of RTIs. The $\sim 2$-fold difference here (with non-VSV-G pseudotyped viruses) is significantly less than the $\sim 1000$-fold difference between untreated and RTI treated samples observed with the VSV-G pseudotyped $\mathrm{NC}_{\mathrm{WT}}$ virus (Figure $2 \mathrm{C}$ ), which again has to do with the prevention of the reinfection of transfected cells using VSV-G pseudotyped virus discussed above. Thus RTI treatment does not appreciably decrease the amount of virus produced from cells. Figure 4 also shows the titers of viruses prepared in the presence or the absence of RTIs from two separate transfection/infection experiments (panels B and $\mathrm{C}$ ). These viruses were PEG precipitated (Figure 1, left) to remove the RTIs. Critically, the titer of wild-type virus is completely unchanged whether the virus is prepared in the absence (black bars) or presence (red bars) of RTIs, firmly establishing that we can effectively remove RTIs from virus preparations. In the case of the $\mathrm{NC}_{\mathrm{H} 23 \mathrm{C}}$ and $\mathrm{NC}_{\mathrm{H} 44 \mathrm{C}}$ viruses, we see that blocking premature reverse transcription using RTIs had no significant effect on infectious titers (Figure $4 \mathrm{~B}$ and $4 \mathrm{C}$ ); importantly, infectivity was not restored to wild-type 


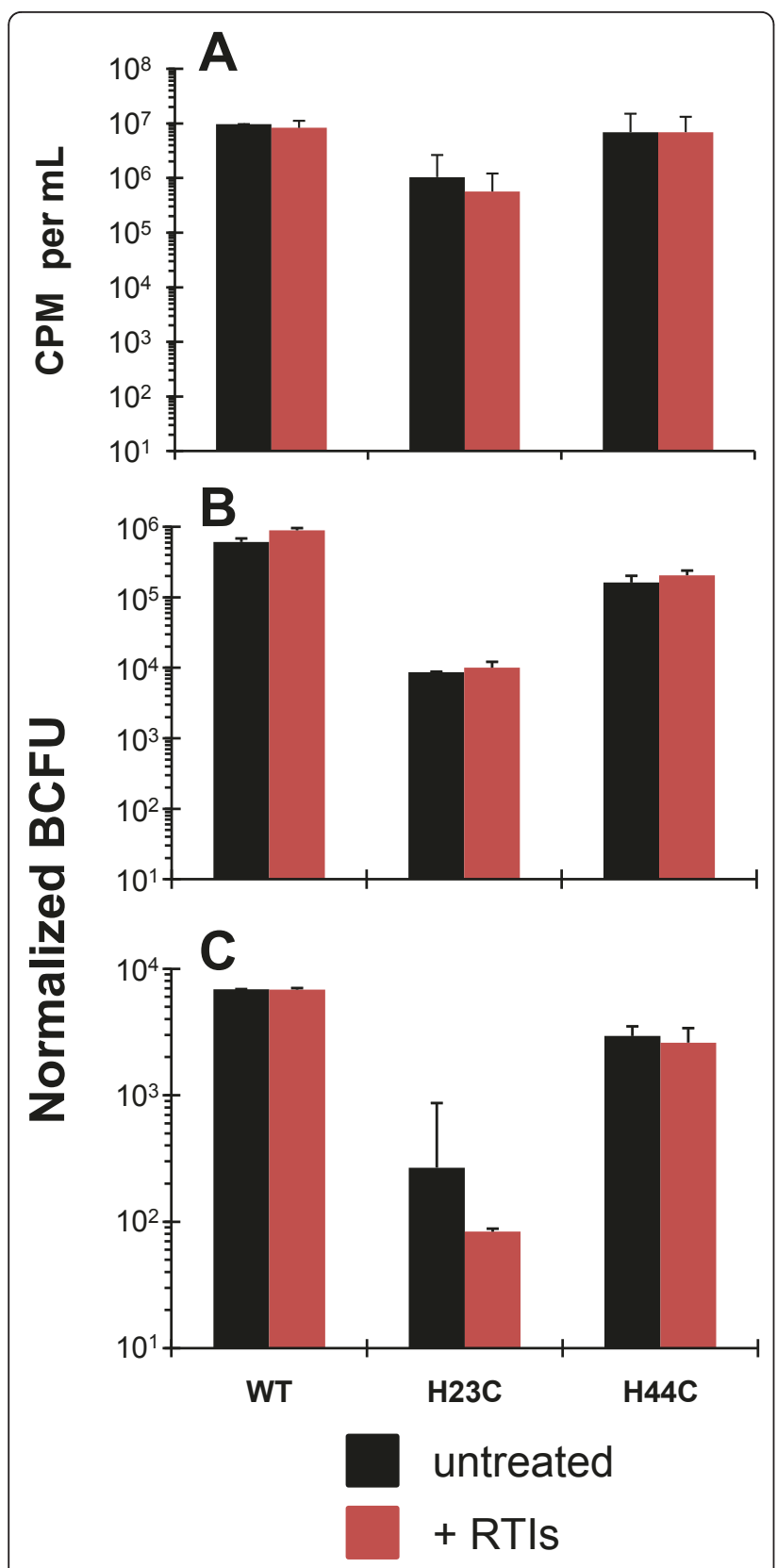

Figure 4 Titer of NC mutant viruses is unchanged if premature reverse transcription is blocked. Results from HIV-1 produced either in the absence (black bars) or the presence (red bars) of RTIs are presented. All viruses produced were PEG precipitated, not just those treated with RTIs for direct comparison. Panel A shows the yields of viruses from transfections, with and without RTI treatment based on average exogenous-template RT activities (in counts per minute of [ $\left.{ }^{32} \mathrm{P}\right]-\mathrm{TMP}$ incorporated per $\mathrm{mL}$ [CPM per $\mathrm{mL}$ ]; error bars are the standard deviation from duplicate samples). Panels B and C are from two independent transfection-infection experiments and each displays the titers of viruses measured using TZM-bl cells, determined from 3-fold serial dilutions [41]. The titer was corrected for dilution and input virus as determined by exogenous-template RT activity and expressed as "Normalized BCFU" from the means of at least 3 dilutions (error bars represent the standard deviation). levels upon RTI treatment with the NC mutants. The relative difference in the titers of $\mathrm{NC}_{\mathrm{WT}}$ to that of the $\mathrm{NC}_{\text {mutants }}$ is what we normally see when viruses are not PEG precipitated ([28]; data not shown).

\section{$\mathrm{NC}_{\text {mutants }}$ display wild-type kinetics during endogenous reverse transcription}

We established that blocking premature reverse transcription did not relieve the infectivity defect; therefore, we investigated the reverse transcription efficiency of the NC-mutant and wild-type viruses using an endogenous reverse transcription assay. As before (Figure 3; [33]) we used our qPCR system to measure the quantities of each reverse transcription intermediate and then normalized the vDNA quantities to the amount of gRNA present at the initiation of the assay to determine the efficiency of conversion of gRNA to reverse transcripts. We prepared the viruses either in the presence or the absence of RTIs, and then treated the viruses with DNase I and subtilisin (Figure 1, right) to remove not only contaminating extra-virion DNA, but the RTIs as well. Each virus preparation was then divided into 7 equal aliquots to examine an endogenous reverse transcription time course.

Figure 5 shows the results of these experiments comparing the amount of each vDNA species measured as a function of time. Panels A and B show endogenous reverse transcription activity from wild-type virus prepared in the absence or the presence of RTIs, respectively. As observed above (Figure 3A) wild-type virus prepared using the RTI treatment results in a decrease of the already low levels of intravirion DNA by approximately 2 logs. This decrease in background actually enables a more accurate determination of endogenous reverse transcription activity. When Figures $5 \mathrm{~A}$ and $5 \mathrm{~B}$ are compared, one can see that although the kinetics of the reactions are similar, the formation of each of the measured reverse transcription products is much more efficient. The final quantities of each intermediate are the same, independent of the presence or absence of RTIs, while the initial quantities are 2-logs lower in virus prepared with RTIs. Closer inspection of Figure 5B shows several important details. Synthesis of R-U5 is very rapid, and every copy of gRNA gives rise to 1 copy of R-U5 vDNA. Synthesis of U3-U5 is also fast, although quantities continue to accumulate until $8 \mathrm{~h}$ into the reaction, when approximately one third of genomes have progressed to maximal U3-U5 vDNA levels. Gag targets are noticeably slower in production, with a more gradual increase to maximum quantities occurring $24 \mathrm{~h}$ into the reaction when approximately one tenth of genomes have progressed to generate maximal Gag vDNA. Finally, synthesis of R-5'UTR vDNA is the slowest with 


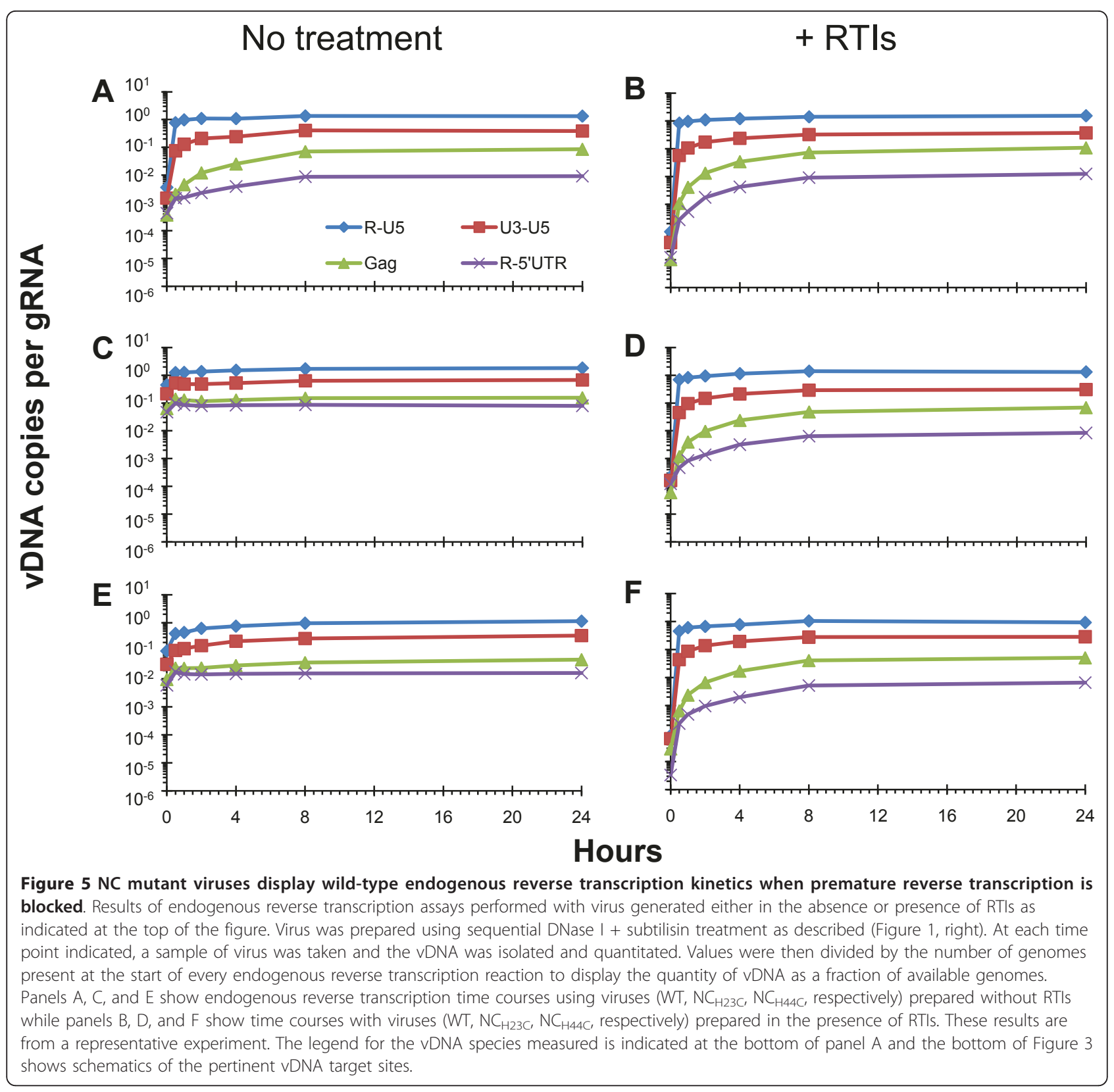

approximately 1 in 80 genomes being reverse transcribed at $24 \mathrm{~h}$.

Examination of the quantities of vDNA present in the

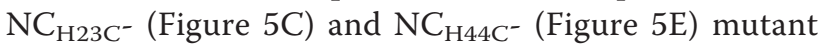
viruses prepared without RTIs reveals a small increase over the time course of the reaction ( 4-10-fold for RU5 DNA). As we reported previously [33], these NC mutants do not have significant endogenous reverse transcription activity, likely due to the lack of available gRNA template because of the premature reverse transcription that has taken place during production of the mutant viruses. However, when we prevent premature reverse transcription using the RTI treatment, we see that both $\mathrm{NC}_{\mathrm{H} 23 \mathrm{C}}$ (Figure $5 \mathrm{D}$ ) and $\mathrm{NC}_{\mathrm{H} 44 \mathrm{C}}$ (Figure $5 \mathrm{~F}$ ) exhibit strong endogenous reverse transcription activity. For each of the vDNA species examined, the kinetics and efficiency of formation are virtually identical to what we observed with wild-type (Figure 5B), with a $\sim 10,000$-fold increase in R-U5 vDNA copies over the time course. Therefore these NC mutants are not defective in any detectable way for reverse transcription that takes place within virions. In addition, this assay demonstrated the likelihood that any PMPA incorporated when the viruses were generated was effectively removed, as the efficiencies and kinetics of this reaction are the same as wild-type. It is possible that some fraction of 
nascent transcripts still contains incorporated PMPA and was not extended, but this population was not apparent in this assay.

\section{Blocking premature reverse transcription does not rescue defective $\mathrm{NC}_{\text {mutant }}$ reverse transcription kinetics in infected cells}

Although the endogenous reverse transcription activity of the NC mutants was essentially wild-type when premature reverse transcription was blocked (Figure 5B, D and $5 \mathrm{~F}$ ), the single-round TZM-bl infectivity of the $\mathrm{NC}$ mutants was still reduced compared to wild-type, even after RTI treatment and removal (Figure 4). Because of this disparity, we decided to examine the reverse transcription activities of these mutants during a time course of infection. We generated virus in the presence or absence of RTIs, then PEG-precipitated the viruses (both RTI-treated and untreated samples; Figure 1, left) to remove the RTIs, DNase I treated the inocula (see Methods section), and infected HeLa clone $1022 \mathrm{CD}^{(+)}$ cells with equivalent amounts of virus, based on exogenous-template RT activities. Cells were then harvested over the time course, total cell DNA was isolated, and vDNA was measured using qPCR. Previously we had reported that using this technique, we were able to see significant differences between wild-type and NCmutant vDNA kinetic profiles [32].

The kinetic profiles of vDNA synthesis during a wildtype infection, with virus prepared without RTIs are shown in Figure 6A. This chart is similar to what we had reported previously-a maximum accumulation of vDNA occurred at $12 \mathrm{~h}$ post infection and by $24 \mathrm{~h}$ post infection the amounts of R-U5 and U3-U5 are about twice those of Gag and R-5'UTR. In addition, we do not see any evidence for reinfection, although it should be theoretically possible (the cells are CD4+ and the proviral clones are Env $\left.{ }^{(+)}\right)$. However, because Env, Nef, and $\mathrm{Vpu}$ can down regulate the CD4 receptor in infected cells $[47,48]$, the lack of reinfection is not necessarily surprising. Figures $6 \mathrm{C}$ and $6 \mathrm{E}$ show the vDNA profiles after infection with the $\mathrm{NC}_{\mathrm{H} 23 \mathrm{C}}$ and $\mathrm{NC}_{\mathrm{H} 44 \mathrm{C}}$ mutants (without RTI treatment), respectively. As we previously reported, quantities of vDNA at $4 \mathrm{~h}$ were similar to wild-type, but unlike wild-type, these were the maximum levels achieved during the entire time course of infection [32].

When we examined vDNA, after infection with wildtype HIV-1 prepared in the presence of RTIs (so that premature reverse transcription was blocked), we saw that the profiles were very similar to those prepared without RTIs (compare panels A and B). The peaks in vDNA syntheses occur at $8 \mathrm{~h}$ rather than $12 \mathrm{~h}$, but the ratios of early and late reverse transcripts are the same at all the time points $24 \mathrm{~h}$ and later. In addition, in this experiment overall levels of vDNA are about 5-fold lower in viruses prepared with RTIs, although this has no significant effect on single-round infectivity (Figure 4). It is likely that the shift in peak time for vDNA during WT infection is due to infecting cells with higher quantities of virus; when we titrate the amount of virus used to infect cells we see a similar shift in peak vDNA times so that the more virus loaded on the cells results in later vDNA peaks (unpublished observations).

During infections with the $\mathrm{NC}_{\mathrm{H} 23 \mathrm{C}}$ mutant virus prepared with RTIs (Figure 6D) we see a different profilealthough initial levels are still the highest, we see an accumulation in reverse transcripts causing a secondary peak at $12 \mathrm{~h}$, then a steeper decrease over the rest of the time course compared to virus prepared without RTIs. In addition, levels of vDNA in the presence of RTIs are about 5-fold lower after infection compared with virus prepared without RTIs (compare Figure 6C and $6 \mathrm{D}$ ), similar to that observed for the wild-type virus set (Figure 6A and 6B). We see analogous results after infection with $\mathrm{NC}_{\mathrm{H} 44 \mathrm{C}}$ mutant virus (panel $\mathrm{F}$ ); an accumulation in reverse transcripts with a peak at $8 \mathrm{~h}$ post infection, but the overall levels are 5-fold lower than in virus prepared without RTIs (compare panels E and F). The accumulation of peak reverse transcripts in NC mutant viruses prepared with RTIs is likely because these virions do not undergo premature reverse transcription, thus reverse transcription initiates after infection, as with wild-type virus. The fact that the overall levels of vDNA are lower in virus prepared with RTIs, yet the TZM-bl infectivity does not change, indicates that the higher levels of intravirion DNA present in infections with virus prepared without RTIs does not contribute to the infectivity of the virus. The loss of R-U5 products after infection (Figure 6C, $6 \mathrm{D}$ and $6 \mathrm{~F}$ ) with the $\mathrm{NC}$ mutants is likely due to degradation of the ends of the viral DNA synthesized as well as the lack of integration, which have been previously reported $[31,49]$.

\section{$\mathrm{NC}_{\mathrm{WT}}$ phenotype is dominant over $\mathrm{NC}_{\text {mutants }}$ and infectivity does not correlate with the extent of premature reverse transcription}

We performed the following experiment to test the relationship between intravirion DNA and infectivity by testing whether the $\mathrm{NC}_{\mathrm{WT}}$ or $\mathrm{NC}_{\text {mutant }}$ phenotypes were dominant. We cotransfected cells with different ratios of $\mathrm{NC}_{\mathrm{WT}}$ and $\mathrm{NC}_{\text {mutant }}$ proviral plasmids and examined the virus for infectivity in TZM-bl cells and also measured quantities of intravirion DNA. Figure 7A shows that as the proportion of $\mathrm{NC}_{\mathrm{WT}}$ (blue line) increases relative to $\mathrm{NC}_{\mathrm{H} 23 \mathrm{C}}$, the amount of intravirion 


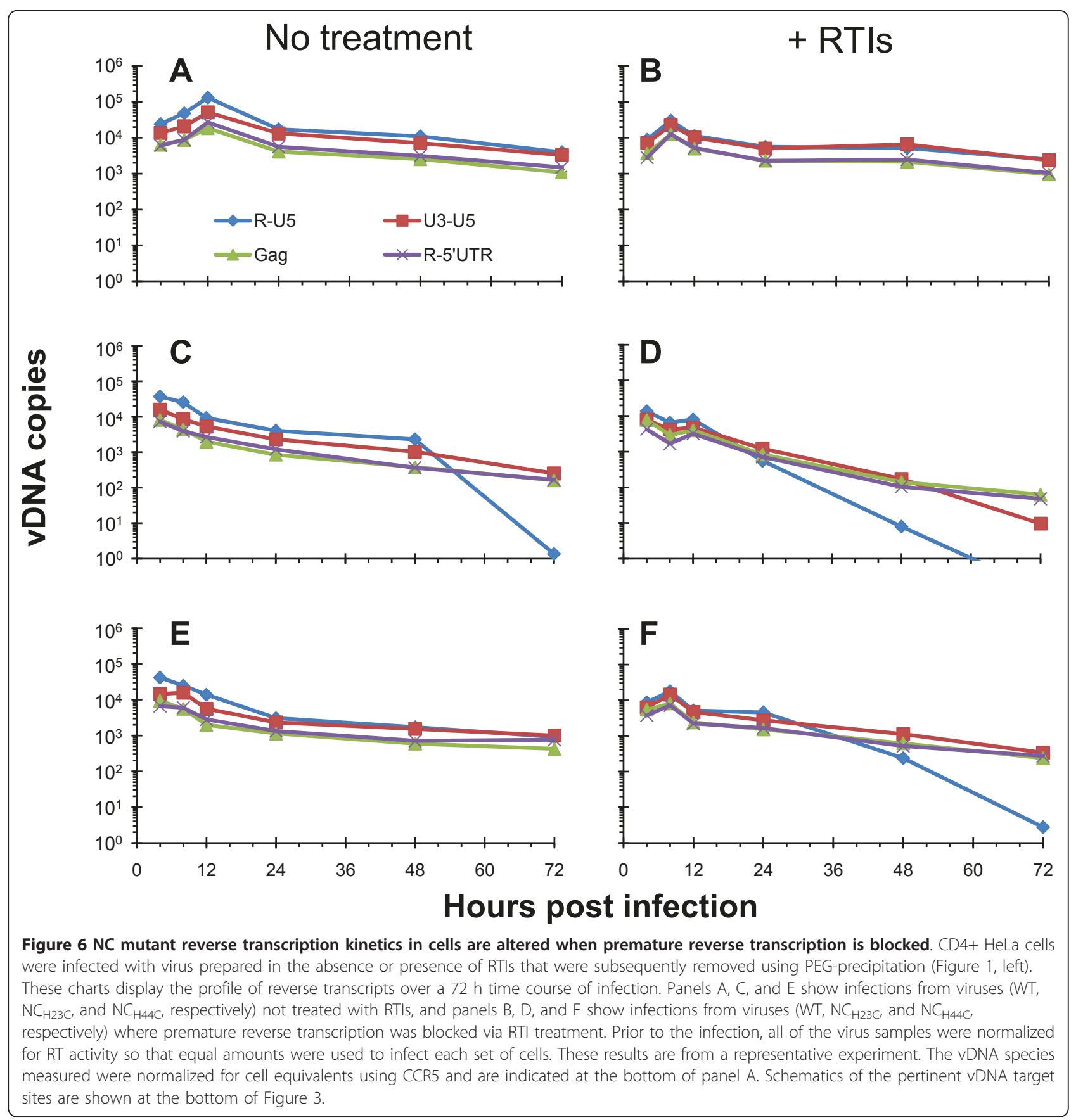

DNA (green line) drops much quicker than the increase in infectivity (red line). However, the increase in infectivity is directly proportional to the increase in the amount of $\mathrm{NC}_{\mathrm{WT}}$. We see a slightly different result with viruses containing different ratios of $\mathrm{NC}_{\mathrm{WT}}$ to $\mathrm{NC}_{\mathrm{H} 44 \mathrm{C}}$ (Figure 7B) because the decrease in intravirion DNA is more gradual with increasing proportions of $\mathrm{NC}_{\mathrm{WT}}$. However, in agreement with what was observed with the $\mathrm{NC}_{\mathrm{H} 23 \mathrm{C}}: \mathrm{NC}_{\mathrm{WT}}$ mixtures, the increase in infectivity mirrors the relative amount of $\mathrm{NC}_{\mathrm{WT}}$ present in the virions. The higher overall levels of infectivity observed with the $\mathrm{NC}_{\mathrm{H} 44 \mathrm{C}}$ mutant in this experiment is due to the inherently higher infectious titer of this mutant virus compared to $\mathrm{NC}_{\mathrm{H} 23 \mathrm{C}}$, (compare red lines between Figures 7A and 7B) which was reported previously [28] and is also apparent in Figure 4. These experiments indicate that the levels of intravirion DNA are independent of the infectivity of these viruses, and that the NC mutations are not dominant over WT HIV-1 with respect to infectivity. 


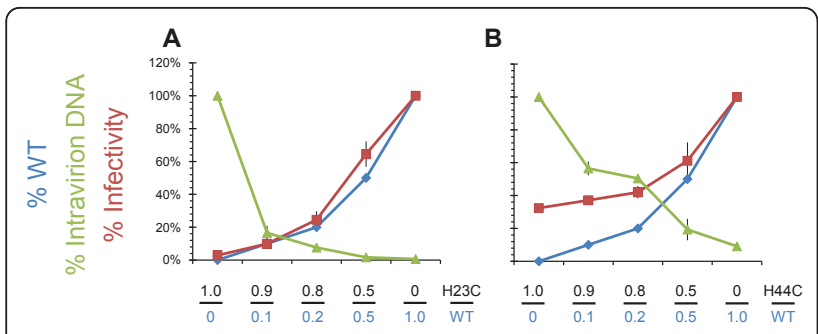

Figure $7 \mathrm{NC}_{\mathrm{WT}}$ phenotype is dominant over $\mathrm{NC}_{\text {mutants }}$ with no correlation between infectivity and premature reverse

transcription. 293T cells were cotransfected with the indicated ratios of $\mathrm{NC}_{W T}$ or $\mathrm{NC}_{\text {mutant }}$ proviral plasmids. The percentage of $N C_{W r}$ in each transfection is shown in blue. The resulting viruses were harvested and infectious titer in TZM-bl cells was determined (red). The resulting titers were corrected for input virus and are expressed as a percentage of WT titer. The amount of intravirion DNA (R-U5) was also quantified in each sample (green), and these values are expressed as a percentage of intravirion DNA present for each respective $\mathrm{NC}_{\text {mutant }}$ virus (so that $100 \%$ mutant is defined as $100 \%$ intravirion DNA). The values are the average of 2 separate experiments and the error bars indicate the standard deviations.

\section{Discussion}

When we observed that the $\mathrm{NC}_{\mathrm{H} 23 \mathrm{C}}$ and $\mathrm{NC}_{\mathrm{H} 44 \mathrm{C}}$ mutations resulted in premature reverse transcription, we did not know if this was a direct, indirect, or unrelated cause of their replication defect [33]. We hypothesized that the presence of intravirion DNA indicates a defective virus. This is based, in part, on observations by Mirambeau and coworkers [50-52] and Cruceanu and coworkers [53] that the mature NC protein (p7) favors binding to single-stranded nucleic acids and binds less tightly to double stranded regions. In addition, Zhang and coworkers reported that when dNTPs were added to extracellular HIV-1 virions, which stimulated reverse transcription, electron micrographs revealed indistinct cores [54]. It seemed reasonable to interpret this core dissolution as being analogous to core uncoating during an infection. Because there is very good evidence that core uncoating is a regulated step during infection [55-59], any event that alters the timing of this could potentially disrupt replication $[60,61]$. Thus, we wanted to see if the replication defect could be rescued by preventing premature reverse transcription in these $\mathrm{NC}$ mutants. To investigate this we developed an experimental system whereby reverse transcription could be reversibly inhibited so that we could examine the effects of blocking the accumulation of high levels of intravirion DNA on infectivity and reverse transcription processes.

In this study, we showed that completely inhibiting premature reverse transcription (Figure 3) did not rescue the single-round infectivity defects associated with the NC mutants (Figure 4). In contrast to this, we found that when premature reverse transcription was blocked, the endogenous reverse transcription kinetics of these mutants could be restored to nearly the wild-type level (Figure 5B, D, and 5F). However, during infection of HeLa CD4+ cells, we did see that the $\mathrm{NC}_{\mathrm{H} 23 \mathrm{C}}$ mutant still showed poor reverse transcription profiles with apparently unstable reverse transcripts (Figure 6D) after RTI treatment. The $\mathrm{NC}_{\mathrm{H} 44 \mathrm{C}}$ mutant showed a profile similar to $\mathrm{NC}_{\mathrm{H} 23 \mathrm{C}}$ virus (compare Figure $6 \mathrm{D}$ and $6 \mathrm{~F}$ ). The difference in reverse transcription efficiencies during endogenous reverse transcription versus infection is probably related to the inability of core components to readily diffuse or "uncoat" from the viral core in the endogenous reverse transcription system, as they are maintained within the viral membrane as is discussed below.

The absolute quantities of vDNAs are lower after infections with viruses prepared in the presence of RTIs compared to those prepared without RTIs (Figure 6), however, the infectious titer remains unchanged (Figure 4). This indicates that the amount of intravirion vDNA is irrelevant with respect to infection readout in the TZM-bl assay. Or stated differently, the altered timing of reverse transcription in the $\mathrm{NC}$ mutants does not significantly change the infectivity of these viruses using TZM-bl cells as the readout. This conclusion is supported by our experiments with $\mathrm{NC}_{\mathrm{WT}}$ and $\mathrm{NC}_{\text {mutant }}$ mixtures. In these experiments, infectious titer is directly related to the amount of $\mathrm{NC}_{\text {WT }}$ present in the virions, not to the amount of intravirion DNA (Figure 7).

The results from our endogenous reverse transcription time course experiments (Figure 5) are important because we did not see that these NC mutations caused any defects in the kinetics or efficiencies of reverse transcription. Several in vitro reverse transcription systems using purified proteins and short defined templates do show reverse transcription defects with these NC mutant proteins $[15,62]$. The reason for these differences may be as straightforward as protein concentrations. Endogenous reverse transcription occurs within the confines of the virus membrane so that even after $24 \mathrm{~h}$ the majority of CA, MA, and NC are still pelletable (data not shown). In addition, if the virus preparations are diluted out prior to endogenous reverse transcription (such as in the time course experiments) the reactions proceed no differently than if the virus is maintained at a high concentration. Because of this, it is likely that during endogenous reverse transcription, the $\mathrm{NC}$ protein is maintained at very high concentrations with respect to the viral gRNA. Based on the volume of the conical core of HIV-1 as estimated from cryo-electron tomography [63], and assuming that each virion contains $2000 \mathrm{NC}$ molecules [64], the effective concentration of NC within the core is $\sim 100 \mathrm{mM}$. 
However, despite the fact that the NC mutants have WT endogenous reverse transcription activity upon RTI treatment with subsequent inhibitor removal (Figure 5B, D, F), in the context of an infection, the NC mutants still show defects in reverse transcription compared to wild-type virus (Figure 6). Thus there is something about reverse transcription within the intracellular environment that prevents these $\mathrm{NC}$ mutants from productively replicating in a cell. Previously, we had postulated that premature reverse transcription may cause altered uncoating or reverse transcription complex maturation [33], but we now know that premature reverse transcription is not the cause of the replication defect. It is important to point out that the reverse transcripts generated during the infection time course (Figure 6D and 6F) appear more unstable with NC-mutant viruses prepared in the presence of RTIs (premature reverse transcription being blocked), which would indicate that integration is still defective. Although we would like to have examined integration directly using the Alu-LTR qPCR assay as we performed in our previous study [32], the sensitivity of this assay is not amenable to the measurement of integration products with non VSV-G pseudotyped virus infections using HeLa CD4+ cells. However, it is possible that $\mathrm{NC}$ is more directly involved during the integration event, as was shown in a previous report using purified integrase and $\mathrm{NC}$ in a cell-free, in vitro assay [26]. In that study, both of these $\mathrm{NC}$ mutants showed a defect in integration compared to wild-type NC. How much this would carry through to infected cells is difficult to say considering that additional viral and cellular protein cofactors are involved $[57,59,65]$.

\section{Conclusions}

We have blocked premature reverse transcription in NC mutant viruses using high levels of RTIs. Upon removal of the inhibitors, the single-round TZM-bl infectivity of these mutants remained the same, independent of whether premature reverse transcription occurred or was blocked. Endogenous reverse transcription assays demonstrated that reverse transcription for these NC mutants displayed wild-type kinetics and efficiencies. However, reverse transcription in the context of an infection was still defective compared to wild-type virus. Cotransfection experiments with various ratios of $\mathrm{NC}_{\mathrm{WT}}$ and $\mathrm{NC}_{\text {mu- }}$ tant plasmids also failed to show any correlation between intravirion DNA and infectivity. Therefore premature reverse transcription is not the clear-cut cause of the replication defect for these viruses, but is likely a symptom of some other defect in the assembly process.

\section{Methods}

\section{Chemicals and plasmids}

Nevirapine was obtained through the AIDS Research and Reference Reagent Program, Division of AIDS, NIAID,
$\mathrm{NIH}$, and handled according to the supplied data sheet (https://www.aidsreagent.org/pdfs/ds4666_004.pdf). Tenofovir (PMPA) was kindly provided by Gilead Sciences, Inc. (Foster City, CA). Construction of the $\mathrm{NC}_{\mathrm{H} 23 \mathrm{C}}$ and $\mathrm{NC}_{\mathrm{H} 44 \mathrm{C}}$ mutants in pNL4-3 (GenBank accession numbers AF324493 and M19921) [66] were previously described [28]. A frameshift mutation was introduced into the env of the indicated proviral clones to prevent expression of Env [67]. The plasmid pHCMVg, which expresses VSV-G [68], was a kind gift from Jane Burns (University of California, San Diego).

\section{Cell culture and transfections}

293T cells [69,70], HeLa CD4+ Clone 1022 (obtained through the AIDS Research and Reference Reagent Program, Division of AIDS, NIAID, NIH: from Dr. Bruce Chesebro https://www.aidsreagent.org/pdfs/ds1109_009. pdf) [71-73], and TZM-bl cells (obtained through the NIH AIDS Research and Reference Reagent Program, Division of AIDS, NIAID, NIH: from Dr. John C. Kappes, Dr. Xiaoyun Wu and Tranzyme Inc. https:// www.aidsreagent.org/pdfs/ds8129_010.pdf) [74-78] were maintained as described $[28,41]$. Transfections were performed using $\mathrm{CaPO}_{4}$ co-precipitation as previously described [32,33] with Env $^{(+)}$virus (Figures 3, 4, 5, 6, 7) or Env ${ }^{(-)} /$VSV-G pseudotyped virus (Figure 2). For RTI treatments we used $50 \mu \mathrm{M}$ NVP and $1 \mathrm{mM}$ PMPA. Both drugs were added just prior to the addition of DNA precipitates to cells. Cell culture fluids were changed $24 \mathrm{~h}$ post transfection and replaced with fresh media containing the same levels of inhibitors. Virus was harvested $48 \mathrm{~h}$ post transfection as described [32,33].

\section{Preparation of virus}

Virus was harvested from transfected cells, clarified by low-speed centrifugation and filtration through a 0.22 $\mu \mathrm{m}$ filter as described [32]. We determined the RT activity using the exogenous template RT assay described below. To remove RTIs from virus preparations for subsequent infectivity assays, we added $1 / 2$ volume of ice-cold 30\% (wt./vol.) PEG (8000 MW) dissolved in $0.5 \mathrm{M} \mathrm{NaCl}$ to the infectious supernatant, then precipitated on ice for at least two h with occasional mixing. Virus-PEG mixtures were then centrifuged at low speed $(6,800 \times g)$ for $15 \mathrm{~min}$ in a prechilled rotor at $4^{\circ} \mathrm{C}$. The supernatant was removed by aspiration, and then the pellets were washed with ice-cold 10\% (wt./ vol.) PEG (1/2 volume of 30\% [wt./vol.] PEG (8000) prepared with 1 vol. of Dulbecco's PBS without $\mathrm{Ca}^{2+}$ or $\mathrm{Mg}^{2+}$ ). After the wash supernatant was removed by aspiration, the tubes were spun briefly to collect any remaining supernatant, which was removed by aspiration. The pellets were resuspended in cell culture media 
and used for infectivity assays (Figure 1, left). For subsequent qPCR analysis of virions and endogenous reverse transcription assays, virus-containing supernatants were treated with DNase I, pelleted through a $20 \%$ sucrose pad, then treated with subtilisin and pelleted through another 20\% sucrose pad as described [33] (Figure 1, right).

\section{Infectivity assays}

TZM-bl cells in 96-well plates were infected with each PEG-precipitated virus preparation (Figure 1, left) using eleven 3 -fold serial dilutions, and the final titer was determined by counting the number of blue colonies in each well and normalizing to the dilution and virus input using exogenous-template RT activity as described [41]. HeLa CD4+ clone 1022 cells were infected with PEG-precipitated virus for $4 \mathrm{~h}$ and cells were harvested at the indicated time points. DNA from infected cells was isolated using a Qiagen DNA Blood Mini-Kit, and viral and cellular DNA sequence targets were quantitated using qPCR as described [32].

\section{Endogenous reverse transcription assays}

Virus treated with DNase I and subtilisin (Figure 1, right) was used in the endogenous reverse transcription assay as described [33]. In contrast with the endpoint assays shown previously, we performed a kinetic analysis by following the progression of reverse transcription over a time course. To do this, each DNase-subtilisin treated virus preparation was divided into 7 equal parts. One part was immediately lysed (50 mM Tris, $\mathrm{pH} 7.4$; 10 mM EDTA; 1\% (w/v) SDS; $100 \mathrm{mM} \mathrm{NaCl} ; 50 \mu \mathrm{g} / \mathrm{mL}$ yeast tRNA; $100 \mu \mathrm{g}$ proteinase $\mathrm{K})$, extracted twice each with phenol:chloroform:isoamyl alcohol (25:24:1) and chloroform, and ethanol precipitated. Viral DNA and gRNA were quantitated to assess the initial levels of vDNA and input genomes for the reverse transcription reactions. The other 6 parts were kept on ice while endogenous reverse transcription buffer was added to each tube (final composition after addition to virus sample, $50 \mathrm{mM}$ Tris- $\mathrm{HCl}$, pH 8.0, $2 \mathrm{mM} \mathrm{MgCl}_{2}, 10 \mathrm{mM}$ dithiothreitol, $25 \mu \mathrm{M}$ [each] dNTPs). All samples were placed at $37^{\circ} \mathrm{C}$ simultaneously, and at the indicated times one part was collected, immediately lysed (as above) and viral DNA was quantitated to determine progression of reverse transcription.

\section{Exogenous-template reverse transcriptase assays}

Virus containing supernatants $(0.75 \mathrm{~mL})$ were clarified by low speed centrifugation and/or filtration and mixed with $0.375 \mathrm{~mL}$ of $30 \%$ (wt./vol.) PEG (8000 MW) dissolved in $0.5 \mathrm{M} \mathrm{NaCl}$. Samples were stored overnight at $4^{\circ} \mathrm{C}$, precipitates were collected by centrifugation at top speed in a microfuge, supernatants were removed and pellets were resuspended in $37.5 \mu \mathrm{L}$ of $50 \mathrm{mM}$ Tris, $100 \mathrm{mM} \mathrm{NaCl}, 1 \mathrm{mM}$ EDTA, 2\% (vol./vol.) fetal bovine serum, $\mathrm{pH}$ 7.5. The resuspended virus $(5 \mu \mathrm{L})$ was assayed in a total volume of $25 \mu \mathrm{L}$ containing $50 \mathrm{mM}$ Tris, $100 \mathrm{mM} \mathrm{NaCl}, 6 \mathrm{mM} \mathrm{MgCl}_{2}, 10 \mathrm{mM}$ dithiothreitol, $4 \mu \mathrm{g} / \mathrm{mL}$ oligo- $\mathrm{dT}_{17}$ (Invitrogen, Carlsbad, CA), $40 \mu \mathrm{g} / \mathrm{mL}$ poly-rA (The Midland Certified Reagent Company, Inc., Midland, TX), $0.01 \mu \mathrm{Ci}\left[\alpha-{ }^{32} \mathrm{P}\right]-\mathrm{TTP}$ (3000 Ci/mmol; Perkin Elmer Life Sciences, Waltham, MA) and $0.25 \%$ (vol./vol.) Nonidet P-40.

Samples were incubated at $37^{\circ} \mathrm{C}$ for $3 \mathrm{~h}$, then $5 \mu \mathrm{L}$ were spotted onto a DEAE Filtermat for the 1450 MicroBeta counter (Perkin Elmer Cat. No.: 1450-5222) and allowed to dry. Filters were washed $3 \times$ in $250 \mathrm{~mL}$ of $0.3 \mathrm{M} \mathrm{NaCl}, 0.03 \mathrm{M}$ sodium citrate, $\mathrm{pH} 7.0$, for 15 min each, then rinsed twice in $10 \mathrm{~mL}$ of $95 \%$ (vol./vol.) ethanol (1 min each) and allowed to dry. The filtermats were counted using a ${ }^{32} \mathrm{P}$-Filtermat Cassette (Perkin Elmer cat. no.: 1450-118) in a Wallac 1450 Microbeta, 6-detector, liquid scintillation counter (Perkin Elmer).

\section{q PCR for vDNA and qRT-PCR for gRNA}

Primers and probes were used for quantitation of gRNA and vDNA using a Stratagene Mx3000P instrument (Agilent Technologies, Santa Clara, CA). All of the primers, probes, and PCR conditions used have been described [32,33]. The targets monitor progression of 4 discrete steps of reverse transcription including minusstrand strong-stop synthesis (R-U5), minus-strand transfer product (U3-U5), late minus-strand synthesis (Gag), and plus-strand transfer product (R-5'UTR). For gRNA determination the primers and probes for gag detection were used (see bottom of Figure 3 for schematics of the pertinent vDNA target sites). CCR5 DNA copies were used to normalize vDNA for cell recovery in infections (Figure 6) as described [32].

\section{Acknowledgements and funding}

This project has been funded in whole or in part with federal funds from the National Cancer Institute, National Institutes of Health, under contract HHSN261200800001E with SAIC-Frederick, Inc. The content of this publication does not necessarily reflect the views or policies of the Department of Health and Human Services, nor does mention of trade names, commercial products, or organizations imply endorsement by the $U$. S. Government.

\section{Authors' contributions \\ JAT and RJG designed the experiments, performed the experiments, analyzed data, and wrote the paper. TLS performed cell culture and assisted with the transfections and infectivity analyses. All authors have read and approved the final version of this manuscript.}

\section{Competing interests}

The authors declare they have no competing interests.

Received: 1 April 2011 Accepted: 17 June 2011 Published: 17 June 2011 


\section{References}

1. Levin JG, Guo J, Rouzina I, Musier-Forsyth K: Nucleic acid chaperone activity of HIV-1 nucleocapsid protein: Critical role in reverse transcription and molecular mechanism. Prog Nucleic Acid Res Mol Biol 2005, 80:217-286.

2. Rein A, Henderson LE, Levin JG: Nucleic-acid-chaperone activity of retroviral nucleocapsid proteins: significance for viral replication. Trends Biochem Sci 1998, 23:297-301.

3. Thomas JA, Gorelick RJ: Nucleocapsid protein function in early infection processes. Virus Res 2008, 134:39-63.

4. Bampi $C$, Jacquenet $S$, Lener D, Decimo D, Darlix JL: The chaperoning and assistance roles of the HIV-1 nucleocapsid protein in proviral DNA synthesis and maintenance. Int J Biochem Cell Biol 2004, 36:1668-1686.

5. Bampi C, Jacquenet $S$, Lener D, Decimo D, Darlix JL: The chaperoning and assistance roles of the HIV-1 nucleocapsid protein in proviral DNA synthesis and maintenance. Curr HIV Res 2004, 2:79-92.

6. Levin JG, Mitra M, Mascarenhas A, Musier-Forsyth K: Role of HIV-1 nucleocapsid protein in HIV-1 reverse transcription. RNA Biol 2010, 7:754-774

7. Godet J, Mely Y: Biophysical studies of the nucleic acid chaperone properties of the HIV-1 nucleocapsid protein. RNA Biol 2010, 7:48-60.

8. Mirambeau G, Lyonnais S, Gorelick RJ: Features, processing states, and heterologous protein interactions in the modulation of the retroviral nucleocapsid protein function. RNA Biol 2010, 7:85-95

9. Khan R, Giedroc DP: Recombinant human immunodeficiency virus type 1 nucleocapsid (NCp7) protein unwinds tRNA. J Biol Chem 1992, 267:6689-6695

10. Hargittai MR, Mangla AT, Gorelick RJ, Musier-Forsyth K: HIV-1 nucleocapsid protein zinc finger structures induce tRNA $($ Lys,3) structural changes but are not critical for primer/template annealing. J Mol Biol 2001, 312:985-997.

11. Guo F, Saadatmand J, Niu M, Kleiman L: Roles of Gag and NCp7 in facilitating tRNA(Lys)(3) Annealing to viral RNA in human immunodeficiency virus type 1. J Virol 2009, 83:8099-8107.

12. Johnson PE, Turner RB, Wu ZR, Hairston L, Guo J, Levin JG, Summers MF: A mechanism for plus-strand transfer enhancement by the HIV-1 nucleocapsid protein during reverse transcription. Biochemistry 2000 39:9084-9091.

13. Guo J, Henderson LE, Bess J, Kane B, Levin JG: Human immunodeficiency virus type 1 nucleocapsid protein promotes efficient strand transfer and specific viral DNA synthesis by inhibiting TAR-dependent self-priming from minus-strand strong-stop DNA. J Virol 1997, 71:5178-5188.

14. Guo J, Wu T, Anderson J, Kane BF, Johnson DG, Gorelick RJ, Henderson LE, Levin JG: Zinc finger structures in the human immunodeficiency virus type 1 nucleocapsid protein facilitate efficient minus- and plus-strand transfer. J Virol 2000, 74:8980-8988.

15. Guo J, Wu T, Kane BF, Johnson DG, Henderson LE, Gorelick RJ, Levin JG: Subtle alterations of the native zinc finger structures have dramatic effects on the nucleic acid chaperone activity of human immunodeficiency virus type 1 nucleocapsid protein. J Virol 2002 76:4370-4378.

16. Rodriguez-Rodriguez L, Tsuchihashi Z, Fuentes GM, Bambara RA, Fay PJ: Influence of human immunodeficiency virus nucleocapsid protein on synthesis and strand transfer by the reverse transcriptase in vitro. $J \mathrm{Bio}$ Chem 1995, 270:15005-15011.

17. You JC, McHenry CS: Human immunodeficiency virus nucleocapsid protein accelerates strand transfer of the terminally redundant sequences involved in reverse transcription. J Biol Chem 1994, 269:31491-31495.

18. Heilman-Miller SL, Wu T, Levin JG: Alteration of nucleic acid structure and stability modulates the efficiency of minus-strand transfer mediated by the HIV-1 nucleocapsid protein. J Biol Chem 2004, 279:44154-44165.

19. Wu T, Heilman-Miller SL, Levin JG: Effects of nucleic acid local structure and magnesium ions on minus-strand transfer mediated by the nucleic acid chaperone activity of HIV-1 nucleocapsid protein. Nucleic Acids Res 2007, 35:3974-3987.

20. Hong MK, Harbron EJ, O'Connor DB, Guo J, Barbara PF, Levin JG, MusierForsyth K: Nucleic acid conformational changes essential for HIV-1 nucleocapsid protein-mediated inhibition of self-priming in minusstrand transfer. J Mol Biol 2003, 325:1-10.
21. Golinelli MP, Hughes SH: Self-priming of retroviral minus-strand strongstop DNAs. Virology 2001, 285:278-290.

22. Drummond JE, Mounts P, Gorelick RJ, Casas-Finet JR, Bosche WJ, Henderson LE, Waters DJ, Arthur LO: Wild-type and mutant HIV type 1 nucleocapsid proteins increase the proportion of long CDNA transcripts by viral reverse transcriptase. AIDS Res Hum Retroviruses 1997, 13:533-543.

23. Ji X, Klarmann GJ, Preston BD: Effect of human immunodeficiency virus type 1 (HIV-1) nucleocapsid protein on HIV-1 reverse transcriptase activity in vitro. Biochemistry 1996, 35:132-143.

24. Klasens BI, Huthoff HT, Das AT, Jeeninga RE, Berkhout B: The effect of template RNA structure on elongation by HIV-1 reverse transcriptase. Biochim Biophys Acta 1999, 1444:355-370.

25. Wu W, Henderson LE, Copeland TD, Gorelick RJ, Bosche WJ, Rein A, Levin JG: Human immunodeficiency virus type 1 nucleocapsid protein reduces reverse transcriptase pausing at a secondary structure near the murine leukemia virus polypurine tract. J Virol 1996, 70:7132-7142.

26. Carteau S, Gorelick RJ, Bushman FD: Coupled integration of human immunodeficiency virus type 1 cDNA ends by purified integrase in vitro: stimulation by the viral nucleocapsid protein. J Virol 1999, 73:6670-6679.

27. Tsuchihashi Z, Brown PO: DNA strand exchange and selective DNA annealing promoted by the human immunodeficiency virus type 1 nucleocapsid protein. J Virol 1994, 68:5863-5870.

28. Gorelick RJ, Gagliardi TD, Bosche WJ, Wiltrout TA, Coren LV, Chabot DJ, Lifson JD, Henderson LE, Arthur LO: Strict conservation of the retroviral nucleocapsid protein zinc finger is strongly influenced by its role in viral infection processes: characterization of HIV-1 particles containing mutant nucleocapsid zinc-coordinating sequences. Virology 1999, 256:92-104.

29. Demene $H$, Dong CZ, Ottmann $M$, Rouyez MC, Jullian N, Morellet N, Mely $Y$, Darlix JL, Fournie-Zaluski MC, Saragosti S, et al: 1H NMR structure and biological studies of the His23->Cys mutant nucleocapsid protein of HIV-1 indicate that the conformation of the first zinc finger is critical for virus infectivity. Biochemistry 1994, 33:11707-11716.

30. Julian N, Demene H, Morellet N, Maigret B, Roques BP: Replacement of His 23 by Cys in a zinc finger of HIV-1 NCp7 led to a change in 1H NMRderived 3D structure and to a loss of biological activity. FEBS Lett 1993, 331:43-48

31. Buckman JS, Bosche WJ, Gorelick RJ: Human immunodeficiency virus type 1 nucleocapsid $\mathrm{Zn}(2+)$ fingers are required for efficient reverse transcription, initial integration processes, and protection of newly synthesized viral DNA. J Virol 2003, 77:1469-1480.

32. Thomas JA, Gagliardi TD, Alvord WG, Lubomirski M, Bosche WJ, Gorelick RJ: Human immunodeficiency virus type 1 nucleocapsid zinc-finger mutations cause defects in reverse transcription and integration. Virology 2006, 353:41-51.

33. Thomas JA, Bosche WJ, Shatzer TL, Johnson DG, Gorelick RJ: Mutations in human immunodeficiency virus type 1 nucleocapsid protein zinc fingers cause premature reverse transcription. J Virol 2008, 82:9318-9328.

34. Didierlaurent L, Houzet L, Morichaud Z, Darlix JL, Mougel M: The conserved $\mathrm{N}$-terminal basic residues and zinc-finger motifs of HIV-1 nucleocapsid restrict the viral cDNA synthesis during virus formation and maturation. Nucleic Acids Res 2008, 36:4745-4753.

35. Houzet L, Morichaud Z, Didierlaurent L, Muriaux D, Darlix JL, Mougel M: Nucleocapsid mutations turn HIV-1 into a DNA-containing virus. Nucleic Acids Res 2008, 36:2311-2319.

36. Mougel $M$, Houzet $L$, Darlix $J \mathrm{~L}$ : When is it time for reverse transcription to start and go? Retrovirology 2009, 6:24.

37. Borroto-Esoda K, Boone LR: Development of a human immunodeficiency virus-1 in vitro DNA synthesis system to study reverse transcriptase inhibitors. Antiviral Res 1994, 23:235-249.

38. Balzarini J, Holy A, Jindrich J, Naesens L, Snoeck R, Schols D, De Clercq E: Differential antiherpesvirus and antiretrovirus effects of the (S) and (R) enantiomers of acyclic nucleoside phosphonates: potent and selective in vitro and in vivo antiretrovirus activities of (R)-9-(2phosphonomethoxypropyl)-2,6-diaminopurine. Antimicrob Agents Chemother 1993, 37:332-338.

39. Merluzzi VJ, Hargrave KD, Labadia M, Grozinger K, Skoog M, Wu JC, Shih CK, Eckner K, Hattox S, Adams J, et al: Inhibition of HIV-1 replication by a nonnucleoside reverse transcriptase inhibitor. Science 1990, 250:1411-1413. 
40. Ott DE, Coren LV, Johnson DG, Sowder RC, Arthur LO, Henderson LE: Analysis and localization of cyclophilin A found in the virions of human immunodeficiency virus type 1 MN strain. AIDS Res Hum Retroviruses 1995, 11:1003-1006

41. Morcock DR, Thomas JA, Sowder RC, Henderson LE, Crise BJ, Gorelick RJ: HIV-1 inactivation by 4-vinylpyridine is enhanced by dissociating $\mathrm{Zn}(2+)$ from nucleocapsid protein. Virology 2008, 375:148-158.

42. Bampi C, Bibillo A, Wendeler M, Divita G, Gorelick RJ, Le Grice SF, Darlix JL: Nucleotide excision repair and template-independent addition by HIV-1 reverse transcriptase in the presence of nucleocapsid protein. J Biol Chem 2006, 281:11736-11743.

43. Boyer PL, Imamichi T, Sarafianos SG, Arnold E, Hughes SH: Effects of the Delta67 complex of mutations in human immunodeficiency virus type 1 reverse transcriptase on nucleoside analog excision. J Virol 2004, 78:9987-9997.

44. Grohmann D, Godet J, Mely Y, Darlix JL, Restle T: HIV-1 nucleocapsid traps reverse transcriptase on nucleic acid substrates. Biochemistry 2008, 47:12230-12240.

45. Abram ME, Ferris AL, Shao W, Alvord WG, Hughes SH: Nature, position, and frequency of mutations made in a single cycle of HIV-1 replication. J Virol 2010, 84:9864-9878.

46. Thomas JA, Shulenin S, Coren LV, Bosche WJ, Gagliardi TD, Gorelick RJ, Oroszlan S: Characterization of human immunodeficiency virus type 1 (HIV-1) containing mutations in the nucleocapsid protein at a putative HIV-1 protease cleavage site. Virology 2006, 354:261-270.

47. Willey RL, Maldarelli F, Martin MA, Strebel K: Human immunodeficiency virus type 1 Vpu protein induces rapid degradation of CD4. J Virol 1992, 66:7193-7200

48. Chen BK, Gandhi RT, Baltimore D: CD4 down-modulation during infection of human T cells with human immunodeficiency virus type 1 involves independent activities of vpu, env, and nef. J Virol 1996, 70:6044-6053.

49. Tanchou V, Decimo D, Pechoux C, Lener D, Rogemond V, Berthoux L, Ottmann M, Darlix JL: Role of the N-terminal zinc finger of human immunodeficiency virus type 1 nucleocapsid protein in virus structure and replication. J Virol 1998, 72:4442-4447.

50. Lyonnais S, Gorelick RJ, Mergny JL, Le Cam E, Mirambeau G: G-quartets direct assembly of HIV-1 nucleocapsid protein along single-stranded DNA. Nucleic Acids Res 2003, 31:5754-5763.

51. Mirambeau G, Lyonnais S, Coulaud D, Hameau L, Lafosse S, Jeusset J, Justome A, Delain E, Gorelick RJ, Le Cam E: Transmission electron microscopy reveals an optimal HIV-1 nucleocapsid aggregation with single-stranded nucleic acids and the mature HIV-1 nucleocapsid protein. J Mol Biol 2006, 364:496-511.

52. Mirambeau G, Lyonnais S, Coulaud D, Hameau L, Lafosse S, Jeusset J, Borde I, Reboud-Ravaux M, Restle T, Gorelick RJ, Le Cam E: HIV-1 protease and reverse transcriptase control the architecture of their nuclecapsid partner. PLoS One 2007, 2:e669.

53. Cruceanu M, Urbaneja MA, Hixson CV, Johnson DG, Datta SA, Fivash MJ, Stephen AG, Fisher RJ, Gorelick RJ, Casas-Finet JR, et al: Nucleic acid binding and chaperone properties of HIV-1 Gag and nucleocapsid proteins. Nucleic Acids Res 2006, 34:593-605.

54. Zhang H, Dornadula G, Orenstein J, Pomerantz RJ: Morphologic changes in human immunodeficiency virus type 1 virions secondary to intravirion reverse transcription: evidence indicating that reverse transcription may not take place within the intact viral core. J Hum Virol 2000, 3:165-172.

55. Stremlau M, Perron M, Lee M, Li Y, Song B, Javanbakht H, Diaz-Griffero F, Anderson DJ, Sundquist WI, Sodroski J: Specific recognition and accelerated uncoating of retroviral capsids by the TRIM5alpha restriction factor. Proc Natl Acad Sci USA 2006, 103:5514-5519.

56. Nisole S, Saib A: Early steps of retrovirus replicative cycle. Retrovirology 2004, 1:9.

57. Warrilow D, Tachedjian G, Harrich D: Maturation of the HIV reverse transcription complex: putting the jigsaw together. Rev Med Virol 2009, 19:324-337.

58. Dismuke DJ, Aiken C: Evidence for a functional link between uncoating of the human immunodeficiency virus type 1 core and nuclear import of the viral preintegration complex. J Virol 2006, 80:3712-3720.

59. Auewarakul P, Wacharapornin P, Srichatrapimuk S, Chutipongtanate $S$, Puthavathana P: Uncoating of HIV-1 requires cellular activation. Virology 2005, 337:93-101.
60. Iordanskiy S, Berro R, Altieri M, Kashanchi F, Bukrinsky M: Intracytoplasmic maturation of the human immunodeficiency virus type 1 reverse transcription complexes determines their capacity to integrate into chromatin. Retrovirology 2006, 3:4.

61. Arhel N: Revisiting HIV-1 uncoating. Retrovirology 2010, 7:96.

62. Williams MC, Gorelick RJ, Musier-Forsyth K: Specific zinc-finger architecture required for HIV-1 nucleocapsid protein's nucleic acid chaperone function. Proc Natl Acad Sci USA 2002, 99:8614-8619.

63. de Marco A, Muller B, Glass B, Riches JD, Krausslich HG, Briggs JA: Structural Analysis of HIV-1 Maturation Using Cryo-Electron Tomography. PLoS Pathog 2010, 6:e1001215.

64. Chertova E, Bess JW Jr, Crise BJ, Sowder IR, Schaden TM, Hilburn JM, Hoxie JA, Benveniste RE, Lifson JD, Henderson LE, Arthur LO: Envelope glycoprotein incorporation, not shedding of surface envelope glycoprotein (gp120/SU), Is the primary determinant of SU content of purified human immunodeficiency virus type 1 and simian immunodeficiency virus. J Virol 2002, 76:5315-5325.

65. Warrilow D, Stenzel D, Harrich D: Isolated HIV-1 core is active for reverse transcription. Retrovirology 2007, 4:77.

66. Adachi A, Gendelman HE, Koenig S, Folks T, Willey R, Rabson A, Martin MA: Production of acquired immunodeficiency syndrome-associated retrovirus in human and nonhuman cells transfected with an infectious molecular clone. J Virol 1986, 59:284-291.

67. Ott DE, Chertova EN, Busch LK, Coren LV, Gagliardi TD, Johnson DG: Mutational analysis of the hydrophobic tail of the human immunodeficiency virus type $1 \mathrm{p} 6(\mathrm{Gag})$ protein produces a mutant that fails to package its envelope protein. J Virol 1999, 73:19-28.

68. Burns JC, Friedmann T, Driever W, Burrascano M, Yee JK: Vesicular stomatitis virus $\mathrm{G}$ glycoprotein pseudotyped retroviral vectors: concentration to very high titer and efficient gene transfer into mammalian and nonmammalian cells. Proc Natl Acad Sci USA 1993, 90:8033-8037.

69. DuBridge RB, Tang P, Hsia HC, Leong PM, Miller JH, Calos MP: Analysis of mutation in human cells by using an Epstein-Barr virus shuttle system. Mol Cell Biol 1987, 7:379-387.

70. Pear WS, Nolan GP, Scott ML, Baltimore D: Production of high-titer helperfree retroviruses by transient transfection. Proc Natl Acad Sci USA 1993, 90:8392-8396

71. Chesebro B, Buller R, Portis J, Wehrly K: Failure of human immunodeficiency virus entry and infection in CD4-positive human brain and skin cells. J Virol 1990, 64:215-221.

72. Chesebro B, Wehrly K: Development of a sensitive quantitative focal assay for human immunodeficiency virus infectivity. J Virol 1988, 62:3779-3788.

73. Chesebro B, Wehrly K, Metcalf J, Griffin DE: Use of a new CD4-positive HeLa cell clone for direct quantitation of infectious human immunodeficiency virus from blood cells of AIDS patients. J Infect Dis 1991, 163:64-70.

74. Platt EJ, Bilska M, Kozak SL, Kabat D, Montefiori DC: Evidence that ecotropic murine leukemia virus contamination in TZM-bl cells does not affect the outcome of neutralizing antibody assays with human immunodeficiency virus type 1. J Virol 2009, 83:8289-8292.

75. Takeuchi Y, McClure MO, Pizzato M: Identification of gammaretroviruses constitutively released from cell lines used for human immunodeficiency virus research. J Virol 2008, 82:12585-12588

76. Wei X, Decker JM, Liu H, Zhang Z, Arani RB, Kilby JM, Saag MS, Wu X, Shaw GM, Kappes JC: Emergence of resistant human immunodeficiency virus type 1 in patients receiving fusion inhibitor (T-20) monotherapy. Antimicrob Agents Chemother 2002, 46:1896-1905.

77. Derdeyn CA, Decker JM, Sfakianos JN, Wu X, O'Brien WA, Ratner L, Kappes JC, Shaw GM, Hunter E: Sensitivity of human immunodeficiency virus type 1 to the fusion inhibitor T-20 is modulated by coreceptor specificity defined by the V3 loop of gp120. J Virol 2000, 74:8358-8367.

78. Platt EJ, Wehrly K, Kuhmann SE, Chesebro B, Kabat D: Effects of CCR5 and CD4 cell surface concentrations on infections by macrophagetropic isolates of human immunodeficiency virus type 1. J Virol 1998, 72:2855-2864.

doi:10.1186/1742-4690-8-46

Cite this article as: Thomas et al:: Blocking premature reverse transcription fails to rescue the HIV-1 nucleocapsid-mutant replication defect. Retrovirology 2011 8:46. 